\title{
Prevalence and distribution of soil-transmitted helminth infection in free-roaming dogs in Bali Province, Indonesia
}

\author{
Kadek Karang Agustina1 ${ }^{1 D}$, Made Suma Anthara ${ }^{2}$, Nengah Anom Adi Nugraha Sibang ${ }^{2}$, Wayan Adi Rinta Wiguna ${ }^{1}$, \\ Jendra Krisna Apramada ${ }^{1}$, Wayan Nico Fajar Gunawan² (D), Ida Bagus Made Oka ${ }^{3}$, Made Subrata ${ }^{4}$ and \\ Nengah Kerta Besung ${ }^{5}$ (D)
}

1. Department of Public Health, The Faculty of Veterinary Medicine, Udayana University, Denpasar, Bali 80225, Indonesia; 2. Department of Veterinary Clinic, The Faculty of Veterinary Medicine, Udayana University, Denpasar, Bali 80225, Indonesia; 3. Department of Parasitology, The Faculty of Veterinary Medicine, Udayana University, Denpasar, Bali 80225, Indonesia; 4. Department of Epidemiology, The Public Health Study Program, Faculty of Medicine Udayana University, Denpasar, Bali 80225, Indonesia; 5. Department of Microbiology, The Faculty of Veterinary Medicine, Udayana University, Denpasar, Bali 80225, Indonesia.

Corresponding author: Kadek Karang Agustina, e-mail: k.agustina@unud.ac.id

Co-authors: MSA: sumanthara@unud.ac.id, NAANS: anom_ady@yahoo.com,WARW: adiwiguna942@gmail.com, JKA: jendrajekes44@gmail.com, WNFG: nico_fajar_g@unud.ac.id, IBMO: okaibm@unud.ac.id, MS: madesubrata@unud.ac.id, NKB: kerta_besung@unud.ac.id.

Received: 13-08-2020, Accepted: 14-01-2021, Published online: 22-02-2021

doi: www.doi.org/10.14202/vetworld.2021.446-451 How to cite this article: Agustina KK, Anthara MS, Sibang NAAN, Wiguna WAR, Apramada JK, Gunawan WNF, Oka IBM, Subrata M, Besung NK (2021) Prevalence and distribution of soiltransmitted helminth infection in free-roaming dogs in Bali Province, Indonesia, Veterinary World, 14(2): 446-451.

\begin{abstract}
Background and Aim: Several free-roaming dogs can be easily found in the public areas of Bali. They go out in search of foods and friends and defecate everywhere. In general, these groups of dogs do not receive good healthcare from their owners and are generally threatened by some disease-causing organisms, especially helminths. This study was conducted to identify and measure the prevalence of soil-transmitted helminths (STHs) that cause infection in free-roaming dogs in Bali Province, Indonesia.
\end{abstract}

Materials and Methods: A total of 1611 fresh dog fecal samples were collected from all areas of Bali Province and subjected to qualitative fecal examination using flotation techniques to obtain STH eggs.

Results: The incidence of STHs in free-roaming dogs was 38.36\%. However, three types of STHs were identified, including Ancylostoma spp., Ascaris spp., and Trichuris spp. Ancylostoma spp. had the highest prevalence of 37.8\%, followed by Ascaris spp. and Trichuris spp. at $6.02 \%$ and $0.87 \%$, respectively. Multiple infections of these worms were also recorded. The polyparasitism prevalence of Ancylostoma spp. and Ascaris spp. was 3.85\%, followed by that of Ancylostoma spp. and Trichuris spp. at $0.5 \%$ and that of Ascaris spp. and Trichuris spp. at $0.06 \%$. There were no altitude-wise differences in the prevalence of STH infection.

Conclusion: The prevalence of STHs was high in free-roaming dogs. This finding necessitates more serious attention as it affects both animal and public health.

Keywords: Ancylostoma spp., Ascaris spp., Bali, distribution, free-roam dogs, prevalence, soil-transmitted helminth, Trichuris spp.

\section{Introduction}

Dogs cannot be separated from human life, and they are often referred to as the Best Friend of Man. Petting a dog, apart from being a hobby, can provide several benefits for the owner. According to some research, a dog used as a pet can have a positive impact on psychology and health [1]. In Bali, dogs are used as both pets and protectors of homes. Therefore, they are free to roam as they are terrestrial animals and the guardians of their territories [2]. The population of free-roaming dogs in Bali is quite high, with the

Copyright: Agustina, et al. Open Access. This article is distributed under the terms of the Creative Commons Attribution 4.0 International License (http://creativecommons.org/licenses/ by/4.0/), which permits unrestricted use, distribution, and reproduction in any medium, provided you give appropriate credit to the original author(s) and the source, provide a link to the Creative Commons license, and indicate if changes were made. The Creative Commons Public Domain Dedication waiver (http:// creativecommons.org/publicdomain/zero/1.0/) applies to the data made available in this article, unless otherwise stated. prevalence reaching $69.71 \%[3,4]$ and $19.4 \%$ in rural and urban areas, respectively [2].

In contrast to the benefits provided, the maintenance patterns of allowing them to roam tend to have adverse effects on the health of the community as well as other animals [5]. As a result, several cases have been reported in the Bali community [6]. Dangerous dog-borne infections can be caused by viruses, bacteria, or parasites [7]. However, specific diseases caused by parasites do not attract the attention of the community, which is because they rarely cause clinical symptoms [8].

Moreover, parasitic worms that commonly infect dogs belong to the nematode species [9]. These types of worms include Ancylostoma spp., Ascaris spp., and Trichuris spp. [10]. They are commonly classified into soil-transmitted helminth (STH) groups [11]. Some types of STH worms that infect dogs have been reported as zoonotic agents, namely, Ancylostoma ceylanicum, 
Ancylostoma caninum, and Toxocara canis [12]. STHs infect both animals and humans through the intake of infective eggs or larvae. Therefore, dogs are known to play a crucial role in the transmission of parasites to other animals and humans [13].

In Bali, several studies have reported the prevalence of worms that infect dogs. For instance, T. canis was reported to infect Kintamani dogs in the Sukawana Village area with a prevalence of $22.22 \%$ [14]. The prevalence of Ancylostoma spp. in tourist areas was reported as 34\% [15]. However, there are no reports on prevalence covering all areas in Bali. Therefore, this study was conducted to investigate the prevalence and type of STH worms in dogs that freely roam throughout the province of Bali, Indonesia.

\section{Materials and Methods}

\section{Ethical approval}

The study only used the dog fecal samples which were collected from the residential alley, street, or other public places. Hence, ethical approval was not necessary.

\section{Study period and location}

This research was conducted from February to November 2019 in the province of Bali, Republic of Indonesia.

\section{Samples}

An observational design with a cross-sectional method was used in this study, and the subjects were the free-roaming dogs in the province of Bali. The study sample was fresh dog feces collected from the subjects. Fresh stools were collected in the morning around the residential alley, street, or other public places and were stored in 10\% formalin before being examined at the laboratory [16]. The Bali government has reported that the dog population in Bali was 647.386 in 2019. This number was the highest in Indonesia compared with other provinces. The majority of dogs are free-roaming (approximately $90 \%$ ), and only $10 \%$ of the dog population is well managed [17]. The study sample was calculated using a formula described elsewhere [18], and a minimum number of 73 samples from each regency was required. A total of 1611 samples were collected from all areas of Bali Province and grouped according to regency into Badung, Gianyar, Klungkung, Bangli, Karangasem, Tabanan, Buleleng, and Denpasar city. In addition, they were categorized based on location elevation. Lowland and highland were determined by the altitude. More than $600 \mathrm{~m}$ above the sea level is categorized as highland, and less than $300 \mathrm{~m}$ is categorized as lowland [19].

\section{Stool examination}

Stool examination was performed by a floating concentration method using a saturated $\mathrm{NaCl}$ substance [20]. The concentration McMaster techniques were used to measure the intensity of infection of each identified worm [21].

\section{Statistical analysis}

The following formula was used to measure the prevalence of STH [22], and the data obtained are presented descriptively. Furthermore, the Chi-square test was used in comparing the prevalence of STH according to the landscape [23].

$$
\text { Prevalence }=\frac{\text { Cases number }}{\text { Total samples }} \times 100
$$

\section{Results and Discussion}

This study demonstrated that the prevalence of STH infection in free-roaming dogs was high $(38.36 \%)$ (Table-1). To the best of our knowledge, this is the first report on free-roaming dogs in Bali, Indonesia, and the obtained data correlated with the report on rural dogs living in farms around the Atlantic forest fragments in Brazil [23]. However, the prevalence determined in this study was lower than previous prevalence rates of $98.8 \%$ in Tacuarembo, Uruguay [24], 95\% in Bangladesh [25], 93.1\% in Durban and Coast, South Africa [26], 78.57\% in Ilam Province of Iran [27], 61.8\% in Italy [28], and 51\% in Debre Zeit, Ethiopia [9]. In contrast, this prevalence was higher than previous prevalence rates of $21.5 \%$ in Mexicali County in Northwest Mexico [29], $16.5 \%$ in Calgary, Alberta [30], and $9.4 \%$ in Northern Germany [31]. Our study shows that free-roaming dogs in Bali spread and contaminate the environment by STH eggs. Therefore, this problem requires serious public and animal health attention because STHs can cause severe health problems in dogs [32], including retarded growth, reduced immune response to infectious diseases, and generalized ill health [33].

Hookworm infection was found to be the most frequent parasite in the investigated dog population, with a prevalence of $37.8 \%$, followed by infections with Ascaris spp. and Trichuris whose respective prevalence rates were $6.02 \%$ and $0.87 \%$ (Tables 2 and 3). Ancylostoma spp. is known to be predominant in the small intestines of animals and humans, among which A. ceylanicum, Ancylostoma braziliense, and A. caninum are known as the disease-causing agents $[32,33]$. Their eggs, which are exclusively thrown, can inevitably infect the soil on which dogs defecate. Humans become infected when their skin

Table-1: The prevalence of STH infection in free-roam dogs and its distribution in Bali Province.

\begin{tabular}{lccc}
\hline Regency & Total sample & STH & \% \\
\hline Bangli & 192 & 97 & 50.52 \\
Tabanan & 290 & 129 & 44.48 \\
Denpasar & 168 & 74 & 44.05 \\
Gianyar & 199 & 84 & 42.21 \\
Negara & 136 & 57 & 41.91 \\
Karangasem & 175 & 63 & 36.00 \\
Badung & 139 & 41 & 29.50 \\
Klungkung & 163 & 43 & 26.38 \\
Buleleng & 149 & 30 & 20.13 \\
Total & 1,611 & 618 & 38.36 \\
\hline
\end{tabular}

STH=Soil-transmitted helminths 
comes in contact with the larvae and make penetration. This would lead to cutaneous larva migration to the site of infection and inflammation [34]. Meanwhile, their clinical manifestations include eosinophilic enteritis, abdominal pain, diarrhea, and less frequent symptoms such as localized myositis and erythema multiforme, and ophthalmological complications may also occur [34,35]. A. ceylanicum is the only hookworm species that causes a patent infection, which is the second most common human ancylostomiasis in Asian countries [36,37]. A. caninum, which is the canine hookworm, remains the leading cause of human eosinophilic enteritis $[36,38,39]$.

The prevalence of hookworm infection in free-roaming dogs in Bali (Tables-2 and 3) was higher than the prevalence rates of $33.03 \%$ in the Ilam Province of Iran [27], 20.23\% in Guangdong, China [40], and 25\% in Chittagong Metropolitan, Bangladesh [25]. However, it was lower than the prevalence rates of $48 \%$ in Malaysia (comprising $71.4 \%$ and $48 \%$ in rural and urban free-roaming dogs, respectively) [41], 40.5\% in Central Italy [28], and $36.6 \%$ in the Ilam Province of Iran [27]. Ancylostoma spp. was not recorded in dogs in Northwest Mexico [29]. Furthermore, it was observed that $10 \%-12 \%$ of hookworm infection intensity was moderate (EPG 3000-10,000) and heavy (EPG > 10,000) (Table-3). Adult worms feed on the blood from the mucosa of the small intestine by opening vessels with their toothed buccal capsule. Therefore, it is the parasitic burden that causes the lesions in the host tissues. Ancylostomiasis causes secondary acute or chronic hemorrhagic anemia, and the amount of blood removed is directly proportional to the weight of the adult parasite [42]. In a mild infection, an iron deficiency will develop microcytic hypochromic anemia [33].

Dogs play a key role in the transmission of Toxocara spp., which are directly transmitted from pets to the human environment without the involvement of vectors or intermediate hosts [43]. Meanwhile, infection occurs when humans accidentally ingest the infected eggs, with children being the most vulnerable [10,44].

Table-2: The prevalence of identified worms infection in free roam dogs and its distribution in Bali Province.

\begin{tabular}{lccccccc}
\hline Regency & Total sample & \multicolumn{5}{c}{ Prevalence } \\
\cline { 3 - 7 } & & Ancylostomiasis & \% & Ascariasis & \% & Trichuriasis & \% \\
\hline Bangli & 192 & 95 & 49.48 & 8 & 4.17 & 0 & 0.00 \\
Badung & 139 & 64 & 46.04 & 7 & 5.04 & 3 & 2.16 \\
Denpasar & 168 & 74 & 44.05 & 13 & 7.74 & 1 & 0.60 \\
Tabanan & 290 & 125 & 43.10 & 11 & 3.79 & 2 & 0.69 \\
Gianyar & 199 & 84 & 42.21 & 10 & 5.03 & 1 & 0.50 \\
Negara & 136 & 52 & 38.24 & 9 & 6.62 & 0 & 0.00 \\
Karangasem & 175 & 57 & 32.57 & 16 & 9.14 & 1 & 0.57 \\
Klungkung & 163 & 33 & 20.25 & 13 & 7.98 & 4 & 2.45 \\
Buleleng & 149 & 25 & 16.78 & 10 & 6.71 & 2 & 1.34 \\
Total & 1.611 & 609 & 37.80 & 97 & 6.02 & 14 & 0.87 \\
\hline
\end{tabular}

Table-3: The intensity of Ancylostoma spp. infection in free-roam dogs and its distribution in Bali Province.

\begin{tabular}{lcccccccc}
\hline Regency & Total sample & Positive sample & Light & \% & Moderate & \% & Heavy & \% \\
\hline Denpasar & 168 & 74 & 19 & 25.68 & 24 & 32.43 & 31 & 41.89 \\
Badung & 139 & 64 & 25 & 39.06 & 22 & 34.38 & 17 & 26.56 \\
Gianyar & 199 & 84 & 26 & 30.95 & 24 & 28.57 & 34 & 40.48 \\
Tabanan & 290 & 125 & 50 & 40.00 & 41 & 32.80 & 34 & 27.20 \\
Bangli & 192 & 24 & 43 & 66.67 & 26 & 25.00 & 26 & 8.33 \\
Klungkung & 163 & 57 & 16 & 31.58 & 6 & 38.60 & 2 & 29.82 \\
Karangasem & 175 & 52 & 18 & 48.08 & 22 & 36.54 & 17 & 15.38 \\
Buleleng & 149 & 25 & 11 & 44.00 & 13 & 52.00 & 1 & 4.00 \\
Negara & 136 & 95 & 25 & 45.26 & 19 & 27.37 & 8 & 27.37 \\
Total & 1.611 & 600 & 233 & 38.83 & 197 & 32.83 & 170 & 28.33 \\
\hline
\end{tabular}

Table-4: The intensity of Ascaris spp. infection in free-roam dogs and its distribution in Bali Province.

\begin{tabular}{lcccccccc}
\hline Regency & Total sample & Positive sample & Light & \% & Moderate & \% & Heavy & \% \\
\hline Denpasar & 168 & 13 & 7 & 53.85 & 5 & 38.46 & 1 & 7.69 \\
Badung & 139 & 7 & 2 & 28.57 & 5 & 71.43 & 0 & 0.00 \\
Gianyar & 199 & 10 & 7 & 70.00 & 1 & 10.00 & 2 & 20.00 \\
Tabanan & 290 & 11 & 5 & 45.45 & 5 & 45.45 & 1 & 9.09 \\
Bangli & 192 & 6 & 7 & 66.67 & 1 & 0.00 & 0 & 33.33 \\
Klungkung & 163 & 16 & 4 & 50.00 & 0 & 18.75 & 2 & 31.25 \\
Karangasem & 175 & 9 & 8 & 44.44 & 3 & 33.33 & 5 & 22.22 \\
Buleleng & 149 & 10 & 6 & 60.00 & 2 & 20.00 & 2 & 20.00 \\
Negara & 136 & 8 & 4 & 87.50 & 3 & 12.50 & 2 & 0.00 \\
Total & 1,611 & 90 & 50 & 55.56 & 25 & 27.78 & 15 & 16.67 \\
\hline
\end{tabular}


Two species of Toxocara that has been reported to infect dogs are T. canis and Toxascaris leonine [30]. The prevalence of Ascaris spp. in Bali province (Tables-2 and 4) are lower than the prevalence rates of $23.33 \%$ reported in Chittagong Metropolitan, Bangladesh [25], 21\% in Ethiopia [9], and 20.6\% in Central Italy [28]. However, it was higher than the prevalence of $5 \%$ reported in Mexicali County [29].

Trichuris spp. are known to cause infection in humans. Moreover, few clinical cases that were triggered by Trichuris vulpis have been reported in Thailand, USA, and Mexico [45]. The prevalence of Trichuris spp. in free-roaming dogs in Bali (Tables-2 and 5) was different from the reports in Bangladesh and Central Italy at 45\% [25] and $17.6 \%$ [28], respectively. Compared with T. vulpis, Trichuris serrate, and Tapeinosperma campanula are the two species of Trichuris that can infect cats.
However, previous studies have reported a low prevalence of whipworm in cats [46].

This study also revealed the presence of multiple infections among the worms. The combination of Ancylostoma spp. and Toxocara spp. was the most common combined infection among all three STH cases (Table-6). However, hookworm and roundworm are the most important parasites affecting dogs worldwide in terms of dispersal as well as risk for animal and human health [10]. In general, this polyparasitism affects not only the body condition, survival, or reproduction but also the metabolism, genetics, or immune investment of the host [47]. Interactions among parasites strongly influence their dynamics and therefore play a major role in structuring populations [48].

Moreover, the incidence of infections with different parasite species is generally increasing at the geographical scale [49]. However, there is still a scarcity of

Table-5: The intensity of Trichuris spp. infection in free-roam dogs and its distribution in Bali Province.

\begin{tabular}{lcccccccc}
\hline Regency & Total sample & Positive sample & Light & \% & Moderate & \% & Heavy & \% \\
\hline Denpasar & 168 & 1 & 1 & 100.00 & 0 & 0.00 & 0 & 0.00 \\
Badung & 139 & 3 & 2 & 66.67 & 1 & 33.33 & 0 & 0.00 \\
Gianyar & 199 & 1 & 1 & 100.00 & 0 & 0.00 & 0 & 0.00 \\
Tabanan & 290 & 2 & 1 & 50.00 & 1 & 50.00 & 0 & 0.00 \\
Bangli & 192 & 3 & 0 & 66.67 & 0 & 0.00 & 0 & 33.33 \\
Klungkung & 163 & 1 & 2 & 100.00 & 0 & 0.00 & 1 & 0.00 \\
Karangasem & 175 & 0 & 1 & 0.00 & 0 & 0.00 & 0 & 0.00 \\
Buleleng & 149 & 2 & 0 & 0.00 & 1 & 50.00 & 1 & 50.00 \\
Negara & 136 & 0 & 0 & 0.00 & 0 & 0.00 & 0 & 0.00 \\
Total & 1.611 & 13 & 8 & 61.54 & 3 & 23.08 & 2 & 15.38 \\
\hline
\end{tabular}

Table-6: The multiple infections of soil-transmitted helminths in free-roam dogs and its distribution in Bali Province.

\begin{tabular}{lccccccccc}
\hline Regency & Total sample & $\mathbf{A + B}$ & $\mathbf{\%}$ & $\mathbf{A + C}$ & $\mathbf{\%}$ & $\mathbf{B + C}$ & $\mathbf{\%}$ & $\mathbf{A + B}+\mathbf{C}$ & \% \\
\hline Bangli & 192 & 10 & 5.95 & 1 & 0.60 & 0 & 0.00 & 0 & 0.00 \\
Badung & 139 & 6 & 4.32 & 3 & 2.16 & 0 & 0.00 & 0 & 0.00 \\
Karangasem & 175 & 11 & 6.29 & 0 & 0.00 & 0 & 0.00 & 0 & 0.00 \\
Denpasar & 168 & 10 & 5.03 & 1 & 0.50 & 0 & 0.00 & 0 & 0.00 \\
Klungkung & 163 & 6 & 4.03 & 0 & 0.00 & 1 & 0.67 & 0 & 0.00 \\
Negara & 136 & 3 & 1.84 & 2 & 1.23 & 0 & 0.00 & 1 & 0.61 \\
Gianyar & 199 & 6 & 3.13 & 0 & 0.00 & 0 & 0.00 & 0 & 0.00 \\
Buleleng & 149 & 4 & 2.94 & 0 & 0.00 & 0 & 0.00 & 0 & 0.00 \\
Tabanan & 290 & 6 & 2.07 & 1 & 0.34 & 0 & 0.00 & 1 & 0.34 \\
Total & 1611 & 62 & 3.85 & 8 & 0.50 & 1 & 0.06 & 2 & 0.12 \\
\hline
\end{tabular}

$\mathrm{A}=$ Ancylostoma spp., $\mathrm{B}=$ Ascaris spp., $\mathrm{C}=$ Trichuris spp.

Table-7: The prevalence of soil-transmitted helminths infection according to the landscape.

\begin{tabular}{|c|c|c|c|c|c|}
\hline \multirow[t]{2}{*}{ Parasite } & \multirow[t]{2}{*}{ Landscape } & \multicolumn{2}{|c|}{ Results } & \multirow[t]{2}{*}{ Total } & \multirow[t]{2}{*}{ p-value } \\
\hline & & Negative & Positive & & \\
\hline \multirow[t]{3}{*}{ STH } & Highland & 209 & 124 & 333 & 0.139 \\
\hline & Lowland & 758 & 520 & 1278 & \\
\hline & Total & 967 & 644 & 1611 & \\
\hline \multirow[t]{3}{*}{ Ancylostoma spp. } & Highland & 211 & 122 & 333 & 0.335 \\
\hline & Lowland & 791 & 487 & 1278 & \\
\hline & Total & 1002 & 609 & 1611 & \\
\hline \multirow[t]{3}{*}{ Ascaris spp. } & Highland & 318 & 15 & 333 & 0.118 \\
\hline & Lowland & 1196 & 82 & 1278 & \\
\hline & Total & 1514 & 97 & 1611 & \\
\hline \multirow{3}{*}{ Trichuris spp. } & Highland & 332 & 1 & 333 & 0.180 \\
\hline & Lowland & 1265 & 13 & 1278 & \\
\hline & Total & 1597 & 14 & 1611 & \\
\hline
\end{tabular}


investigations in disease and evolutionary ecology on the impacts of multiple infections on individual hosts or higher parasite species richness on populations $[47,49]$.

The Bali area consists of both highland and lowland, although primarily lowland, and highland is found only in Tabanan, Bangli, and Singaraja regencies. Our analysis also showed that the differences in altitude had no effect on the prevalence of STH infection in free-roaming dogs in Bali (Table-7). Therefore, this finding differs from the case of helminthiasis in rodents that were strongly influenced by landscape characteristics [50].

\section{Conclusion}

The prevalence of STH infection in free-roaming dogs in Bali was high (38.36\%). The STHs causing infection in dogs in Bali were Ancylostoma spp. (37.8\%), Ascaris spp. (6.02\%), and Trichuris spp. $(0.87 \%)$. Moreover, polyparasitism occurs in multiple infections caused by Ancylostoma spp. and Ascaris spp. In addition, the difference in altitude does not affect the prevalence of STH infection. Therefore, it is reasonable to conclude that the high prevalence of STH infection in free-roaming dogs in Bali is consistent with the life cycle of the parasite in the investigated area.

\section{Authors' Contributions}

KKA: Designed the study, performed the laboratory work, analyzed the data, and wrote the manuscript. MSA: Designed the study, collected the samples, performed laboratory work, analyzed the data, and wrote the manuscript. NAANS: Collected the samples, performed laboratory work, analyzed the data, and wrote the manuscript. WARW: Collected the samples, performed the laboratory work, analyzed the data, and wrote the manuscript. JKA: Collected the samples and performed the laboratory work. WNFG: Analyzed the data, and wrote the manuscript. IBMO: Performed the laboratory work, and analyzed the data. MS: Performed the laboratory work, and data analysis. NKB: Analyzed the data, and wrote the manuscript. All authors read and approved the final manuscript.

\section{Acknowledgments}

The authors are thankful to The Dean of the Faculty of Veterinary Medicine and The Rector of Udayana University, Indonesia, for funding this research through Study Program Research Grant with Contract No. 0774/UN14.2.9/LT/2018 and Udayana Excellent Grant Program with Contract No. 0803/UN14.2.9/LT/2018.

\section{Competing Interests}

The authors declare that they have no competing interests.

\section{Publisher's Note}

Veterinary World remains neutral with regard to jurisdictional claims in published institutional affiliation.

\section{References}

1. Walsh, F. (2009) Human-animal bonds II: The role of pets in family systems and family therapy. Fam. Process, 48(4): 481-499.

2. Hiby, E., Agustina, K.K., Atema, K.N., Bagus, G.N., Girardi, J., Harfoot, M., Haryono, Y., Hiby, L., Irawan, H., Kalalo, L., Purnama, S.G., Subrata, I.M., Swacita, I.B.N., Utami, N.W.A., Januraga, P.P. and Wirawan, D.N. (2018) Dog ecology and rabies knowledge of owners and non-owners in Sanur, a sub-district of the Indonesian Island province of Bali. Animals, 8(7): 1-18.

3. Agustina, K.K., Cahyani, P.S.D. and Suardana, I.B.K. (2017) Dog Demography and level of knowledge against rabies in positive and negative case of rabies areas in Mendoyo-Jembrana, Bali, Indonesia. J. Vet., 18(4): 642-648.

4. Utami, N.W.A., Agustina, K.K., Atema, K.N., Bagus, G.N., Girardi, J., Harfoot, M., Haryono, Y., Hiby, L., Irawan, H., Januraga, P.P., Kalalo, L., Purnama, S.G., Subrata, I.M., Swacita, I.B.N., Swarayana, I.M.I., Wirawan, D.N. and Hiby, E. (2019) Evaluation of community-based dog welfare and rabies project in Sanur, a sub-district of the Indonesian island province of Bali. Front. Vet. Sci., 6(7): 1-12.

5. Medina-Pinto, R.A., Rodríguez-Vivas, R.I. and BolioGonzález, M.E. (2018) Zoonotic intestinal nematodes in dogs from public parks in Yucatán, México. Biomedica, 38(1): 105-110.

6. Dalem, T.I.A., Puja, I.K. and Kardena, I.M. (2012) Ekologi dan Demografi Anjing di Kecamatan Denpasar Timur. Indones. Med. Vet., 1(2): 160-172.

7. Pedersen, N.C. (1999) A review of immunologic diseases of the dog. Vet. Immunol. Immunopathol., 69(2-4): 251-342.

8. Agustina, K.K., Swacita, I.B.N., Oka, I.B.M., Dwinata, I.M., Traub, R.J., Cargill, C. and Damriyasa, I.M. (2017) Reducing zoonotic and internal parasite burdens in pigs using a pig confinement system. Vet. World, 10(11): 1347-1352.

9. Yacob, H.T., Ayele, T., Fikru, R. and Basu, A.K. (2007) Gastrointestinal nematodes in dogs from Debre Zeit, Ethiopia. Vet. Parasitol., 148(2): 144-148.

10. Traversa, D. (2012) Pet roundworms and hookworms: A continuing need for global worming. Parasit. Vectors, 5(91): 1-19.

11. Jia-Chi, C., Abdullah, N.A., Shukor, N., Jaturas, N., Richard, R.L., Majid, M.A.A., Guo-Jie, B.M., Mahboob, T., Tan, T.C., Sawangjaroen, N. and Nissapatorn, V. (2016) Soil transmitted helminths in animals-how is it possible for human transmission? Asian Pac. J. Trop. Dis., 6(11): 859-863.

12. Crompton, D.W.T. (2000) The public health importance of hookworm disease. Parasitology, 121(S1): S39-S50.

13. World Health Organization. (2016) Zoonoses and the Human-Animal-Ecosystems Interface. World Health Organization, Geneva. Available from: https://www.who. int/zoonoses/en Retrieved on 21-01-2020.

14. Evayana, M., Dwinata, I.M. and Puja, I.K. (2017) The prevalence of Toxocara canis infection in Kintamani dogs in Sukawana Village, Kintamani Subdistrict, Bangli Regency, Bali. Indones. Med. Vet., 6(2): 115-123.

15. Dharma, P.P.N., Oka, I.B.M. and Dharmawan, N.S. (2017) The prevalence of Ancylostoma spp. infection in dogs on tourism area in Bali. Indones. Med. Vet., 6(3): 230-237.

16. CDC. (2016) Stool Specimens-Specimen Processing. DPDx-Laboratory Identification of Parasites of Public Health Concern. Available from: https://www.cdc.gov/ $\mathrm{dpdx} /$ diagnosticprocedures/stool/specimenproc.html . Retrieved on 21-01-2020.

17. Budiarta, N. (2020) Tekan Kasus Rabies, Pemprov Bali Distribusikan 532.157 Vaksin Kepada Kabupaten-Kota se-Bali. News, Bali Puspa. Available from: https://www. balipuspanews.com/tekan-kasus-rabies-pemprov-bali-distribusikan-532-157-vaksin-kepada-kabupaten-kota-se-bali. html\#: :text=melalui dinas pertanian dan ketahanan,cukup tinggi\%2c sekitar 647.386 ekor. Retrieved on 01-08-2020. 
18. Pourhoseingholi, M.A., Vahedi, M. and Rahimzadeh, M. (2013) Sample size calculation in medical studies. Gastroenterol. Hepatol. Bed Bench, 6(1): 14-7.

19. Widawati, M., Nurjana, M.A. and Mayasari, R. (2018) The Anopheles spp. Species diversity between highland and lowland in Nusa tenggara timur province. Aspirator, 10(2): 103-110.

20. Labs, M. (2015) Flotation Technique for Fecal Parasite Concentration Methods, Parasitology. Available from: http://www.medical-labs.net/flotation-technique-for-fecal-parasite-concentration-methods-3117. Retrieved on 12-01-2019.

21. Vadlejch, J., Petrtýl, M., Zaichenko, I., Čadková, Z., Jankovská, I., Langrová, I. and Moravec, M. (2011) Which McMaster egg counting technique is the most reliable? Parasitol. Res., 109(5): 1387-1394.

22. Eupati. (2015) Epidemiologic Concepts: Incidence and Prevalence, European Patients' Academy. Available from: https://www.eupati.eu/pharmacoepidemiology/epidemiologic-concepts-incidence-and-prevalence. Retrieved on 12-01-2019.

23. Curi, N.H.A., Paschoal, A.M.O., Massara, R.L., Santos, H.A., Guimarães, M.P., Passamani, M. and Chiarello, A.G. (2017) Risk factors for gastrointestinal parasite infections of dogs living around protected areas of the Atlantic Forest: Implications for human and wildlife health. Braz. J. Biol., 77(2): 388-395.

24. Malgor, R., Oku, Y., Gallardo, R. and Yarzabal, L. (1996) High prevalence of Ancylostoma spp. infection in dogs, associated with endemic focus of human cutaneous larva migrans, in Tacuarembo, Uruguay. Parasite, 3(2): 131-134.

25. Das, S., Alim, M.A., SIkder, S., Das Gupta, A. and Masuduzzaman, M. (2012) Prevalence and worm load of enteric helminthiasis in stray dogs of Chittagong Metropolitan, Bangladesh. YYU Vet. Fak. Derg., 23(3): 141-145.

26. Mukaratirwa, S. and Singh, V.P. (2010) Prevalence of gastrointestinal parasites of stray dogs impounded by the society for the prevention of cruelty to animals (SPCA), Durban and Coast, South Africa. J. S. Afr. Vet. Assoc., 81(2): 123-125.

27. Bahrami, A., Doosti, A., Nahravanian, H., Noorian, A.M. and Asbchin, S.A. (2011) Epidemiological survey of gastrointestinal parasites in stray dogs and cats. Aust. J. Basic Appl. Sci., 5(9): 1944-1948.

28. de Liberato, C., Berrilli, F., Odorizi, L., Scarcella, R., Barni, M., Amoruso, C., Scarito, A., di Filippo, M.M., Carvelli, A., Iacoponi, F. and Scaramozzino, P. (2018) Parasites in stray dogs from Italy: Prevalence, risk factors and management concerns. Acta Parasitol., 63(1): 27-32.

29. Trasviña-Muñoz, E., López-Valencia, G., Centeno, P.Á., Cueto-González, S.A., Monge-Navarro, F.J., TinocoGracia, L., Núñez-Castroa, K., Pérez-Ortiza, P., MedinaBasultoa, G.E., Tamayo-Sosaa, A.R. and Gómez-Gómez, D. (2017) Prevalence and distribution of intestinal parasites in stray dogs in the Northwest area of Mexico. Aust. J. Vet. Sci., 49(2): 105-111.

30. Joffe, D., van Niekerk, D., Gagne, F., Gilleard, J., Kutz, S. and Lobingier, R. (2011) The prevalence of intestinal parasites in dogs and cats in Calgary, Alberta. Can. Vet. J., 52(12): 1323-1328.

31. Becker, A.C., Rohen, M., Epe, C. and Schnieder, T. (2012) Prevalence of endoparasites in stray and fostered dogs and cats in Northern Germany. Parasitol. Res., 111(2): 849-857.

32. Savilla, T.M., Joy, J.E., May, J.D. and Somerville, C.C. (2011) Prevalence of dog intestinal nematode parasites in South Central West Virginia, USA. Vet. Parasitol., 178(1-2): 115-120.

33. Qadir, S., Dixit, A.K., Dixit, P. and Sharma, R.L. (2011) Intestinal helminths induce haematological changes in dogs from Jabalpur, India. J. Helminthol., 85(4): 401-403.

34. CDC. (2014) Zoonotic Hookworm FAQs. U.S., Department of Health and Human Services. Available from: https:// www.cdc.gov/parasites/zoonotichookworm/gen_info/faqs. $\mathrm{html}$. Retrieved on 02-02-2019.

35. Rehman, A., Akhtar, R., Akbar, H., Riaz, F., Rashid, I., Shehzad, W., Islam, S., Bajwa, A.A. and Waqas, M. (2017) First report of the molecular detection of ancylostoma caninum in Lahore, Pakistan: The threat from pets. Vet. Med. (Praha), 62(10): 559-564.

36. Traub, R.J., Inpankaew, T., Sutthikornchai, C., Sukthana, Y. and Thompson, R.C.A. (2008) PCR-based coprodiagnostic tools reveal dogs as reservoirs of zoonotic ancylostomiasis caused by Ancylostoma ceylanicum in temple communities in Bangkok. Vet. Parasitol., 155(1-2): 67-73.

37. Liu, Y., Zheng, G., Alsarakibi, M., Zhang, X., Hu, W., Lin, L., Tan, L., Luo, Q., Lu, P. and Li, G. (2014) The zoonotic risk of Ancylostoma ceylanicum isolated from stray dogs and cats in Guangzhou, South China. Biomed. Res. Int., 2014(1): 208759.

38. Traub, R.J., Robertson, I.D., Irwin, P., Mencke, N. and Thompson, R.C.A. (2004) The prevalence, intensities and risk factors associated with geohelminth infection in tea-growing communities of Assam, India. Trop. Med. Int. Health, 9(6): 688-701.

39. Bahgat, M.A., El-Gindy, A.E., Mahmoud, L.A., Hegab, M.H. and Shahin, A.M. (1999) Evaluation of the role of Ancylostoma caninum in humans as a cause of acute and recurrent abdominal pain. J. Egypt. Soc. Parasitol., 29(3): 873-882.

40. Fu, Y., Huang, Y., Abuzeid, A.M.I., Hang, J., Yan, X., Wang, M., Liu, Y., Sun, Y., Ran, R., Zhang, P. and Li, G. (2019) Prevalence and potential zoonotic risk of hookworms from stray dogs and cats in Guangdong, China. Vet. Parasitol. Reg. Stud. Reports, 17(6): 100316.

41. Mahdy, M.A.K., Lim, Y.A.L., Ngui, R., Fatimah, M.S., Choy, S.H., Yap, N.J., Al-Mekhlafi, H.M., Ibrahim, J. and Surin, J. (2012) Prevalence and zoonotic potential of canine hookworms in Malaysia. Parasit. Vectors, 5(1): 88.

42. Lefkaditis, M. (2001) Ancylostomiasis in dogs. Sci. Parasitol., 1(1): 15-22.

43. Deplazes, P., van Knapen, F., Schweiger, A. and Overgaauw, P.A.M. (2011) Role of pet dogs and cats in the transmission of helminthic zoonoses in Europe, with a focus on echinococcosis and toxocarosis. Vet. Parasitol., 182(1): 41-53.

44. Overgaauw, P.AM. and van Knapen, F. (2013) Veterinary and public health aspects of Toxocara spp. Vet. Parasitol., 193(4): 398-403.

45. Areekul, P., Putaporntip, C., Pattanawong, U., Sitthicharoenchai, P. and Jongwutiwes, S. (2010) Trichuris vulpis and T. trichiura infections among schoolchildren of a rural community in Northwestern Thailand: The possible role of dogs in disease transmission. Asian Biomed., 4(1): 49-60.

46. Ketzis, J.K., Shell, L., Chinault, S., Pemberton, C. and Pereira, M.M. (2015) The prevalence of Trichuris spp. infection in indoor and outdoor cats on St. Kitts. J. Infect. Dev. Ctries., 9(1): 111-113.

47. Bordes, F. and Morand, S. (2011) The impact of multiple infections on wild animal hosts: A review. Infect. Ecol. Epidemiol., 1(1): 1-10.

48. Vaumourin, E., Vourc'h, G., Gasqui, P. and VayssierTaussat, M. (2015) The importance of multiparasitism: Examining the consequences of co-infections for human and animal health. Parasit. Vectors, 8(1): 1-13.

49. Rigaud, T., Perrot-Minnot, M.J. and Brown, M.J.F. (2010) Parasite and host assemblages: Embracing the reality will improve our knowledge of parasite transmission and virulence. Proc. Biol. Sci., 277(1701): 3693-3702.

50. Froeschke, G. and Matthee, S. (2014) Landscape characteristics influence helminth infestations in a peri-domestic rodent-implications for possible zoonotic disease. Parasit. Vectors, 7(1): 1-13. 